\title{
ПРИМЕНЕНИЕ КОМПЛЕКСНОГО ПРЕПАРАТА НА ОСНОВЕ ХЛОРГЕКСИДИНА ДЛЯ ЛЕЧЕНИЯ ЭНДОМЕТРИТОВ У КОРОВ
}

\author{
K.V. Poty, V.I. Pleshakova, N.A. Leshcheva
}

\section{THE APPLICATION OF INTEGRATED PRODUCT BASED ON CHLORGEXIDINE FOR THE TREATMENT OF ENDOMETRITIS IN COWS}

Потий Константин Витальевич - соиск. каф. ветеринарной микробиологии, инфекционных болезней Омского государственного аграрного университета им. П.А. Столыпина, г. Омск.

E-mail: konstantin-potij@yandex.ru

Плешакова Валентина Ивановна - д-р ветеринар. наук, проф., зав. каф. ветеринарной микробиологии, инфекционных болезней Омского государственного аграрного университета им. П.А. Столыпина, г. Омск. E-mail: vi.pleshakova@omgau.org

Лещева Надежда Алексеевна - канд. ветеринар. наук, доц. каф. ветеринарной микробиологии, инфекционных болезней Омского государственного аграрного университета им. П.А. Столыпина, г. Омск. E-mail: lescheva@list.ru

Значительное место среди инфрекционной патологии репродуктивной системы коров занимают эндометриты, которые составляют в среднем от 25,5 до 40 \% среди акушерскогинекологической патологии. В наше время наиболее часто данную патологию обуславливает условно-патогенная микрофолора. Кроме того, использование наиболее часто применяемых лекарственных средств не дает терапевтической эфрфективности или она очень низкая. В связи с этим разработка новых антибактериальных средств и схем лечения послеродового эндометрита у коров является актуальной задачей. Нами был разработан и протестирован новый комплексны й препарат на основе хлоргексидина при лечении гнойнокатарального эндометрита, обусловленного Escherichia coli, Staphylococcus aureus, Proteus vulgaris, Citrobacter freundii, Enterococcus faecalis, которые регистрировались в ассоциациях, представленных 2-3 возбудителями. Установлено, что введение препарата в рекомендованной дозе нормализует микробиоценоз маточно-
Poty Konstantin Vitalyevich - Applicant, Chair of Veterinary Microbiology, Infectious Diseases, Omsk State Agrarian University named after P. A. Stolypin, Omsk. E-mail:

konstantin-potij@yandex.ru

Pleshakova Valentina Ivanovna - Dr. Veterinary Sci., Prof., Head, Chair of Veterinary Microbiology, Infectious Diseases, Omsk State Agrarian University named after P.A. Stolypin, Omsk.

E-mail: vi.pleshakova@omgau.org

Leshcheva Nadezhda Alexeevna - Cand. Veterinary Sci., Assoc. Prof., Chair of Veterinary Microbiology, Infectious Diseases, Omsk State Agrarian University named after P. A. Stolypin, Omsk.

E-mail: lescheva@list.ru

цервикального содержимого в сторону уменьшения содержания количества патогенных и условно-патогенных микроорганизмов. Кроме того, у животных, которым применяли разработанный препарат, улучшался протеиновый профиль крови и наблюдалось усиление факторов естественной резистентности, в частности увеличение показателей лизоцимной и бактерицидной активности сыворотки крови. При этом отмечено сокращение сроков клинического выздоровления больных послеродовым эндометритом коров по сравнению с животными, которым проводили базовое лечение, а оплодотворяемость составляла $100 \%$. Следовательно, можно констатировать, что предложенный комплексный препарат на основе хлоргексидина обладает высокой антимикробной активностью, положительно влияет на регенеративные процессы в слизистой оболочке матки и активно стимулирует фракторы неспецисичческой резистентности.

Ключевые слова: коровы, послеродовые эндометриты, микрофрлора, лечение. 
A significant place among infectious pathologies of reproductive system of the cows falls on endometritis, which averages from 25.5 to $40 \%$ among obstetric and gynecological pathologies. Nowadays, most often this pathology is caused by conditionally pathogenic microflora. In addition, the use of the most common drugs does not give therapeutic efficacy or it is very low. In this regard, the development of new antibacterial agents and treatment regimens for postpartum endometritis in cows is urgent. A new complex preparation based on chlorhexidine in the treatment of purulentcatarrhal endometritis caused by Escherichia coli, Staphylococcus aureus, Proteus vulgaris, Citrobacter freundii, Enterococcus faecalis, registered in associations represented by 2-3 pathogens have been developed and tested. It has been found that the introduction of the drug in recommended dose normalized the microbiocenosis of the uterine-cervical contents in the direction of reducing the content of the number of pathogenic and conditionally pathogenic microorganisms. Besides, in animals to which developed preparation was used, the protein profile of the blood was improved and there was an increase in the factors of natural resistance, and in particular, an increase in the indices of lysozyme and bactericidal activity of blood serum. At the same time, there was a reduction in clinical recovery time for the cows sick with postpartum endometritis of compared with animals that underwent basic treatment, and fertility was $100 \%$. Therefore, it can be stated that the proposed complex preparation based on chlorhexidine has high antimicrobial activity and positively affects regenerative processes in the uterine mucosa and actively stimulates non-specific resistant factors.

Keywords: cows, postpartum endometritis, microflora, treatment.

Введение. Послеродовые воспалительные заболевания половых органов у животных представляют важнейшую ветеринарную, технологическую, экологическую проблему в современном животноводстве, так как являются одной из основных причин снижения плодовитости, молочной продуктивности и преждевременной выбраковки животных. Частота их проявлений может достигать 30-40 \% и более [1-6].

Значительное место среди инфекционной патологии репродуктивной системы коров занимают эндометриты, которые составляют от 25,5 до $38,3 \%$ среди акушерско-гинекологической патологии [7-10]. В связи с этим в последние годы проводятся научные изыскания по разработке новых, высокоэффрективных лекарственных препаратов преимущественно антимикроб- ного действия $[1,7,8,11]$. Вместе с тем они не всегда оказываются достаточно эффективными из-за расширения спектра этиологической структуры заболевания (стафрилококки, стрептококки, эшерихии, энтерококки, протей, коринебактерии, микоплазмы, хламидии, грибы, вирусы), а также проявления ассоциативной инфекции, усиления вирулентности выделяемых микроорганизмов и их множественной антибиотикорезистентности.

Цель исследования. Сравнительное изучение чувствительности сочленов микробиоценоза, выделенных из экссудата матки больных гнойно-катаральным эндометритом коров, к используемым в ветеринарной практике препаратам, а именно «Эндометромаг-Т» и предложенному препарату на основе хлоргексидина, который также содержит преднизолон, димексид, салициловую кислоту, а в качестве основы глицерин, дистиллированную воду и масло растительное.

Материал и методы исследования. Объектом исследования служили коровы красностепной породы 4-6-летнего возраста, массой тела 450-542 кг, с молочной продуктивностью 4228-4733 кг за лактацию. Распространение акушерско-гинекологических заболеваний изучали на 200 коровах.

Диагноз на заболевание органов репродуктивной системы ставили на основании первичного зоотехнического учета, результатов вагинального, ректального и клинического исследований.

Для изучения лечебной эффективности препаратов при терапии коров, больных гнойнокатаральным эндометритом, были сформированы три группы по 15 голов в каждой, по принципу аналогов.

Коровам I группы вводили препарат на основе хлоргексидина внутриматочно в дозе 50 г на одно введение при помощи шприца Жанэ и полистироловой пипетки. Лечение проводили с интервалом 48 часов 3 раза за курс. Коровам II группы вводили препарат «Эндометромаг-Т» внутриматочно, в дозе 100 мл с интервалом 48 часов. Животные III группы служили контролем.

При осмотре коров определяли температуру тела животных, пульс и количество дыхательных движений, состояние половых органов, наличие или отсутствие выделений, их цвет, консистенцию и запах. Вагинальное исследование проводили при помощи влагалищного зеркала с осветителем. При этом учитывали состояние слизистой оболочки влагалища и влагалищной части шейки матки, их целостность, положение 
шейки матки, а также характер и количество маточных выделений.

У коров с клиническими признаками эндометритов цервикально-вагинальное содержимое для микробиологических исследований брали с помощью стерильной пипетки. Бактериологические исследования проводили в Омской областной ветеринарной лаборатории. Посевы проб осуществляли на МПБ, МПА, МПА с $5 \%$-й дефибринированной кровью барана, МПА с 7,5\%-й натрия хлорида, МПА с 1\%-й глюкозой, среды Эндо и Сабуро.

Культивирование микроорганизмов проводили в термостате при температуре $37^{\circ} \mathrm{C}$.

Идентификацию микроорганизмов проводили с учетом морфологических, культурных и биохимических свойств микроорганизмов по общепринятым методикам, руководствуясь «Basgey's Manual of systematic Bacteriology» $[12,13]$.

Определение чувствительности выделенных микроорганизмов к антибактериальным препаратам проводили на среде АГВ методом диффузии в агар.

Гематологические и биохимические исследования сыворотки крови проводили общепринятыми методами, руководствуясь методическими указаниями Н.П. Кондрахина и др. (2004).

Бактерицидную активность сыворотки крови (БАСК) исследовали нефелометрическим методом по О.В. Смирновой и др. (1966), лизоцимную активность сыворотки крови (ЛАСК) по В.Г. Дорофрейчук (1968).

Клиническую оценку терапевтической эффективности предложенного препарата на основе хлоргексидина при послеродовом гнойнокатаральном эндометрите проводили в сравнении С препаратом «Эндометромаг-Т», который использовали в хозяйстве для лечения патологий репродуктивных органов коров.

Полученный цифровой материал обрабатывали с помощью биометрических методов с использованием прикладных программ Microsoft office. Statistics 1.2 с вычислением критерия Стьюдента.

Результаты исследования и их обсуждение. Анализ зооветеринарной отчетности в хозяйстве, а также собственные наблюдения показали, что послеродовая патология репродуктивных органов у коров имеет довольно значительное распространение. Так, за период 20182019 гг. задержание последа наблюдалось у $30,11 \%$ коров, эндометриты в 48,3 случаев, из них острые послеродовые составили 16,32 \%, хронические - 11,92 \%, субклинические 19,32 \%. При этом катаральная форма эндомет- рита отмечалась у 6,32 \% коров, гнойнокатаральная у 28,32, гнойная у $4,12 \%$ животных.

Проведенные исследования показали, что первые клинические признаки послеродового гнойно-катарального эндометрита отмечались на 6-7-е сутки после родов и характеризовались выделением из матки коричневых, желтоватых, а иногда серовато-белых лохий. В 18,3 \% случаев регистрировали выделения в виде мелких порошкоподобных или хлопьевидных кусочков разрушенных корункулов, а также фррагментов разлагающегося последа. На 10-12-е сутки выделяющийся цервикально-вагинальный экссудат приобретал в 22,3 \% случаев слизистый и в $74,2 \%$ - слизисто-гнойный характер. Слизистая оболочка влагалища и шейки матки была гиперемирована, отечная, в некоторых случаях с повреждениями. Необходимо отметить, что общее состояние коров в большинстве случаев $(78,3 \%)$ оставалось в пределах клинической нормы. В то же время у 21,7 \% коров при более тяжелом течении воспалительного процесса отмечали повышение температуры тела до $40^{\circ} \mathrm{C}$, угнетение, плохой аппетит.

Установлено, что после применения комплексного препарата на основе хлоргексидина у коров I опытной группы диагностировали увеличение выделений гнойно-катарального экссудата из матки на 1-2-е сутки лечения, а на 4-й день выделение гнойного экссудата прекращалось. В то же время во II опытной группе животных, которым применяли «Эндометромаг-Т», увеличение выделений гнойно-катарального характера из матки наблюдали позже по срокам - на 3-4-е сутки, процесс выделений завершался на 8-9-е сутки.

Проведенное микробиологическое исследование вагинально-маточного содержимого коров показало, что при гнойно-катаральном эндометрите выделяемая микрофлора была представлена следующими таксономическими единицами: Escherichia coli, Staphylococcus aureus, Proteus vulgaris, Citrobacter freundii, Enterococcus faecalis.

Все выделенные микроорганизмы встречались в ассоциациях. Наиболее часто регистрировали сочетание 2 и 3 бактерий. Так, в $31 \%$ случаев отмечали ассоциации Staphylococcus aureus и Escherichia coli, в $20 \%$ - Escherichia coli, Staphylococcus aureus, Proteus vulgaris. Значительно реже $(4,3 \%)$ регистрировали ассоциации в составе 4 микроорганизмов: Escherichia coli, Staphylococcus aureus, Citrobacter freundii, Proteus vulgaris.

Установлено, что наибольшая зона подавления роста большинства выделенных культур 
микроорганизмов была установлена у комплексного препарата на основе хлоргексидина. Для Escherichia coli она составила 26,2士0,75 мм; Enterococcus faecalis $-29,3 \pm 0,86 \mathrm{~mm}$; Priteus vulgaris

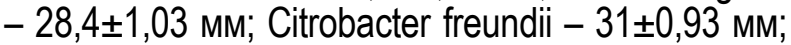
Staphylococcus aureus $-24,8 \pm 1,21 \mathrm{~mm}$.

В то же время зона ингибиции культур протестированных микроорганизмов к препарату «Эндометромаг-Т» составляла для Escherichia

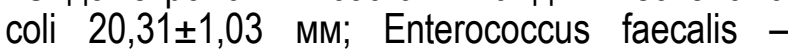
$23,6 \pm 0,82 \mathrm{~mm}$; Proteus vulgaris $21,32 \pm 0,99 \mathrm{~mm}$; Citrobacter freundii - 26,8 $\pm 1,06$ мm; Staphylococcus aureus $-19,6 \pm 0,98 \mathrm{~mm}$.

Необходимо указать, что к концу лечения у коров I опытной группы происходило изменение состава сочленов микробиоценоза содержимого матки коров. Так, произошло уменьшение содержания патогенных микроорганизмов, а именно Proteus vulgaris, Staphylococcus aureus.

Проведенные клинические наблюдения показали, что после применения коровам с гнойнокатаральным эндометритом базового препарата «Эндометромаг-Т» оплодотворяемость в первую половую охоту составила $15,0 \%$, во вторую 50,0 , в третью - 35,0 \%. Всего оплодотворилось $80 \%$ коров. В то же время при использовании предложенного комплексного препарата на основе хлоргексидина оплодотворяемость составила в первую половую охоту - $30 \%$, во вторую -65 , в третью - 100,0 \% от числа животных в группе.
Кроме того, установлено, что при лечении больных коров препаратом «Эндометромаг-Т» выздоровление животных наблюдали в течение $20,1 \pm 0,38$ дней, тогда как применение комплексного препарата на основе хлоргексидина умень-

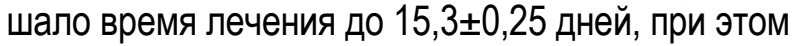
терапевтическая эффрективность к концу курса лечения достигла $88,1 \%$.

Проведенные морфо-биохимические и иммунологические исследования крови коров опытных групп показали, что после применения комплексного препарата на основе хлоргексидина в крови происходило незначительное уменьшение числа лейкоцитов, при этом увеличивалось количество эритроцитов и гемоглобина соответственно на 33,2 и 17,4 \% по сравнению с контрольной группой животных. Также у коров I опытной группы регистрировали увеличение общего белка и альбуминов по сравнению с животными II и III группы. Необходимо отметить, что у коров I опытной группы, которым внутриматочно вводили комплексный препарат на основе хлоргексидина, по сравнению с животными II и III групп отмечали увеличение показателей естественной резистентности, В частности ЛАСК и БАСК. Так, БАСК у коров I группы была на 9,4 \% больше, чем у животных III группы, и на 6,3 \%, чем у коров II группы. Указанную тенденцию наблюдали и в динамике ЛАСК (табл.).

\section{Гематологические показатели коров при лечении гнойно-катарального эндометрита}

\begin{tabular}{|c|c|c|c|}
\hline Показатель & 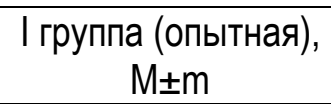 & $\begin{array}{c}\text { II группа (опытная), } \\
\text { M } \pm m\end{array}$ & 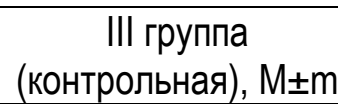 \\
\hline 1 & 2 & 3 & 4 \\
\hline Лейкоциты, $10^{9}$ г/л & $7,23 \pm 0,28$ & $8,21 \pm 0,53$ & $10,01 \pm 0,29$ \\
\hline Эритроциты, $10^{2}$ г/л & $9,26 \pm 0,48^{*}$ & $7,03 \pm 0,33$ & $6,2 \pm 0,22$ \\
\hline Гемоглобин, г/л & $98,3 \pm 1,83^{*}$ & $90,3 \pm 1,34^{*}$ & $82,6 \pm 0,33$ \\
\hline Общий белок, г/л & $77,4 \pm 1,08$ & $71,6 \pm 0,89$ & $66,9 \pm 1,02$ \\
\hline Альбумины & $43,3 \pm 0,38$ & $40,4 \pm 1,04$ & $30,2 \pm 1,34$ \\
\hline а-глобулины & $23,8 \pm 1,18$ & $24,9 \pm 1,09$ & $25,6 \pm 2,03$ \\
\hline$\beta$-глобулины & $11,3 \pm 0,16$ & $11,0 \pm 0,12$ & $11,8 \pm 0,33$ \\
\hline ү-глобулины & $36,4 \pm 0,88$ & $34,2 \pm 0,93$ & $35,3 \pm 1,39$ \\
\hline ЛАСК, \% & $32,3 \pm 0,86^{*}$ & $30,6 \pm 0,97$ & $29,4 \pm 1,03$ \\
\hline БАСК, \% & $48,3 \pm 1,04^{*}$ & $42,6 \pm 1,32$ & $41,3 \pm 1,42$ \\
\hline
\end{tabular}

Примечание: ЛАСК - лизоцимная активность сыворотки крови, БАСК - бактерицидная активность сыворотки крови; * - p $\leq 0,05$.

Заключение. Учитывая результаты проведенных исследований, можно констатировать, что предложенный комплексный препарат на основе хлоргексидина обладает высокой анти- микробной активностью, положительно влияет на регенеративные процессы в слизистой оболочке матки, а также активно стимулирует гуморальные и клеточные факторы иммунитета. 


\section{Литература}

1. Иноземцев В.П. Акушерско-гинекологические болезни у коров в сельхозпредприятиях России // Итоги и перспективы научных исследований по проблемам патологии животных и разработке средств и методов терапии и профилактики: мат-лы коорд. совещания. Воронеж, 1995. С. 254.

2. Нежданов А.Г., Масайлов В.Д., Шахов А.Г. Болезни органов размножения у коров и проблемы их диагностики, терапии и профрилактики // Мат-лы Междунар. науч.практ. конф. Воронеж, 2005. С. 8-11.

3. Микрофрлора при послеродовых эндометритах свиноматок на промышленном свиноводческом комплексе / Н.В. Шульгин, В.И. Плешакова, Т.И. Лоренгель [и др.] // Вестник КрасГАУ. 2019. № 7 (148). С. 89-95.

4. Микрофрлора свиноматок при послеродовых эндометритах в условиях промышленного свиноводческого комплекса / В.И. Плешакова, Н.В. Шульгин, А.А. Жерносенко [и др.] // Вестник КрасГАУ. 2018. № 4 (139). С. 64-68.

5. Metritis complex in Michigan Holstein - Frisian cattle: incidence, descriptive epidemiology and estimated economic impact / Bartlett, P.C., J.H. Kirk [et al.] // Prev. Vet. Med. 1986, 4; P. 235-245.

6. Reppert E.J. Evidence for the use of ceftiofur for treatment of maturities in dairy cattle / Vetclin. North Am Food Animal Pract. 2005, 3 (10). C. 139-149.

7. Воскобойник В.Ф., Козлов Г.П. Эфффективный метод лечения коров с послеродовым эндеметритом // Ветеринария. 1991. № 7. C. 35-36.

8. Дегтярева С.С., Коба И.С. Видовой состав и чувствительность микроорганизмов из смывов шейки матки при послеродовом гнойно-катаральном эндометрите у коров // Актуальные проблемы ветеринарии в современных условиях: мат-лы междунар. науч.-практ. конф., посвящ. 60-летию ГНУ Краснодарского НИВИ. Краснодар, 2006. C. 336-338.

9. Калашников В.А. Роль условно-патогенной микрофолоры в возникновении послеродовых заболеваний половых органов у коров //
Ветеринарная медицина: межвед. темат. науч. сб. Одесса, 2002. Вып. 80. С. 276-277.

10. Hiamer P., Arls S. [et al.]. Antibiotic treatment of martinis is dairy cows-A-meta-analysis. // J. Dairy sci. 2017, 100 (5). P. 3783-3795.

11. Петров А.М., Мирзахметов Ш.Р. Разработка эффрективного метода лечения коров при эндометрите // Ветеринария. 2006. № 5. C. $37-40$.

12. Биргер М.О. Справочник по микробиологическим и вирусологическим методам исследования. М.: Медиум, 1967. 463 с.

13. Berger's Manual of Systematic Bacteriology Book Review. Jut. // J. of Syst. Bact. Jyly 1985. P. 408.

\section{Literatura}

1. Inozemcev V.P. Akushersko-ginekologicheskie bolezni u korov v sel'hozpredprijatijah Rossii // Itogi i perspektivy nauchnyh issledovanij po problemam patologii zhivotnyh i razrabotke sredstv i metodov terapii i profilaktiki: mat-ly koord. soveshhanija. Voronezh, 1995. S. 254.

2. Nezhdanov A.G., Masajlov V.D., Shahov A.G. Bolezni organov razmnozhenija u korov i problemy ih diagnostiki, terapii i profilaktiki // Mat-ly Mezhdunar. nauch.-prakt. konf. Voronezh, 2005. S. 8-11.

3. Mikroflora pri poslerodovyh jendometritah svinomatok na promyshlennom svinovodcheskom komplekse / N.V. Shul'gin, V.I. Pleshakova, T.I. Lorengel' [i dr.] // Vestnik KrasGAU. 2019. № 7 (148). S. 89-95.

4. Mikroflora svinomatok pri poslerodovyh jendometritah $\mathrm{v}$ uslovijah promyshlennogo svinovodcheskogo kompleksa / V.I. Pleshakova, N.V. Shul'gin, A.A. Zhernosenko [i dr.] /I Vestnik KrasGAU. 2018. № 4 (139). S. 64-68.

5. Metritis complex in Michigan Holstein - Frisian cattle: incidence, descriptive epidemiology and estimated economic impact / Bartlett, P.C., J.H. Kirk [et al.] // Prev. Vet. Med. 1986, 4; R. 235-245.

6. Reppert E.J. Evidence for the use of ceftiofur for treatment of maturities in dairy cattle / Vetclin. North Am Food Animal Pract. 2005, 3 (10). S. 139-149. 
7. Voskobojnik V.F., Kozlov G.P. Jeffektivnyj metod lechenija korov s poslerodovym jendemetritom // Veterinarija. 1991. № 7. S. 35-36.

8. Degtjareva S.S., Koba I.S. Vidovoj sostav i chuvstvitel'nost' mikroorganizmov iz smyvov shejki matki pri poslerodovom gnojnokataral'nom jendometrite u korov // Aktual'nye problemy veterinarii v sovremennyh uslovijah: mat-ly mezhdunar. nauch.-prakt. konf., posvjashh. 60-letiju GNU Krasnodarskogo NIVI. Krasnodar, 2006. S. 336-338.

9. Kalashnikov V.A. Rol' uslovno-patogennoj mikroflory v vozniknovenii poslerodovyh zabolevanij polovyh organov u korov // Veterinar- naja medicina: mezhved. temat. nauch. sb. Odessa, 2002. Vyp. 80. S. 276-277.

10. Hiamer P., Arls $S$. [et al.]. Antibiotic treatment of martinis is dairy cows-A-meta-analysis. // J. Dairy sci. 2017, 100 (5). P. 3783-3795.

11. Petrov A.M., Mirzahmetov Sh.R. Razrabotka jeffektivnogo metoda lechenija korov pri jendometrite // Veterinarija. 2006. № 5. S. 37-40.

12. Birger M.O. Spravochnik po mikrobiologicheskim i virusologicheskim metodam issledovanija. M.: Medium, 1967. $463 \mathrm{~s}$.

13. Berger's Manual of Systematic Bacteriology Book Review. Jut. // J. of Syst. Bact. Jyly 1985. P. 408. 